\title{
THE RELIABILITY OF AN INSTRUMENT TO MEASURE TEACHER KNOWLEDGE FROM THE PERSPECTIVE OF LEARNERS IN THE CONTEXT OF PIBID
}

\author{
Keysy S. C. Nogueira, Carmen Fernandez \\ University of São Paulo, Brazil \\ E-mail: keysynogueira@usp.br, carmen@iq.usp.br
}

\begin{abstract}
This research sought to analyze the reliability of an instrument to measure teacher knowledge of a group of pre-service chemistry teachers participating in the Institutional Program for Scholarships for Beginner Teachers in Brazil (PIBID).. Thus, it was analyzed the evaluation of a group of students about the Pedagogical Content Knowledge (PCK) of five pre-service chemistry teachers from the program. Accordingly, an instrument containing 28 statements and an open question was applied to a group of 70 students from a public school to whom the pre-service teachers had applied their didactic proposals. The purpose of the instrument was to measure the perception of the students' about the components of the teacher knowledge (Subject Matter Knowledge - SMK, Instructional Representation and Strategies - IRS, Instructional Objective and Context - IOC and Knowledge of Students' Understanding - KSU) of the preservice teachers. The results of the analysis revealed that the instrument about teacher's knowledge has a high reliability based on the alpha Cronbach values. The results of the alpha coefficient for the pre-service teachers were all above 0.9 suggesting that the instrument is reliable and has consistent measurements. Regarding to the exploratory analysis, the main scale in the PCK evaluation of the undergraduates was four which means that the students consider that the aspects related to the SMK, IRS, IOC and KSU are frequently present in the classes of the future teachers.
\end{abstract}

Keywords: instrument reliability, PIBID, redox reactions, teaching knowledge, PCK.

\section{Introduction}

In the scientific literature there are several authors dealing with the knowledge necessary to be a teacher. Shulman conceived of a knowledge base inherent in the teaching profession (Shulman, 2004). The author proposed seven knowledge categories for teachers (Shulman, 1987), particularly Pedagogical Content Knowledge (PCK), which represents knowledge that distinguishes a chemistry teacher from a chemistry specialist, being specific for each subject and developed in practice (Fernandez, 2014). Shulman's proposals inspired other researchers to investigate PCK (Grossman, 1990; Magnusson, Krajcik \& Borko, 1999; Rollnick \& Mavhunga, 2014; Van Driel \& Verloop, 1998; Fernandez, 2015).

Socialized studies on PCK mean that the participants of the studies are generally teachers who teach in basic education and they are based on a qualitative approach, which suggests that research analyzing the PCK of university professors and pre-service teachers is rare. However, despite being in early stages, some researchers started to develop questionnaires to measure the PCK of teachers (Kleickmann et al. 2013; Kirschner, Borowski, Fischer, Gess-Newsome \& Von Aufschnaiter, 2016). Among the quantitative studies, though, few analyze student perceptions of the teachers' knowledge of their respective professors (Criua \& Marian, 2014; Halim \& Abdullah, 2014; Jang, 2011; Sofianidis \& Kallery, 2016; Tuan, Chang, Wang \& Treagust, 
Keysy S. C. NOGUEIRA, Carmen FERNANDEZ. The reliability of an instrument to measure teacher knowledge from the perspective of learners in the context of PIBID

\section{PROBLEMS \\ OF EDUCATION \\ IN THE $21^{\text {st }}$ CENTURY Vol. 76, No. 1, 2018 \\ 70}

2000). Jang, Guan and Hsieh (2009) developed a Likert scale type instrument to measure how undergraduate students perceived the PCK of their professors. In assessing the results, the authors argue that professors began to consider student understanding over teaching strategies used in the teaching environment. This instrument was used in other studies (Girotto Júnior, 2015; Jang, 2011; Sofianidis \& Kallery, 2016). In one of these researches, Girotto Júnior (2015) applied it to undergraduate students in chemistry. The results of the instrument were compared to the view of the researcher based on one phase of their studies with qualitative characteristics. The analyses imply that the students are aware of their professors' knowledge of practice, but they have difficulty in recognizing other types of knowledge, which are part of out-of-class activities, such as, for example, class planning and issues related to the prior knowledge of the students. Possible inconsistencies between perceptions by students and outside observers of teacher knowledge can be a reflection of the different aspects each one observes (Peterson, Wahlquist \& Bone, 2000).

Therefore, the aim of the research is to analyze the reliability of an instrument on teacher knowledge of five pre-service chemistry teachers who participate in the "Programa Institucional de Bolsa de Iniciação à Docência (PIBID)", Institutional Scholarship Program for Beginning Teachers.

\section{Program for Beginning Teachers - (PIBID)}

The Programa Institucional de Bolsa de Iniciação à Docência (PIBID, "Institutional Scholarship Program for Beginning Teachers") is a relatively recent Brazilian policy that promotes and values the teaching career. It enables undergraduate students to have teaching experience during the undergraduate course (Braibante \& Wollmann, 2012; Gatti, Barreto \& André, 2011; Scheibe, 2010). Its purpose is to promote the integration between basic education and higher education, promoting reflections on the educational practice and to promote professional development of teachers (Canan, 2012; Ribeiro \& Nogueira, 2016). In this sense, PIBID has been considered a third educational space, in addition to undergraduate studies and the supervised internship (Felício, 2014). Research on this program are dedicated to investigating mainly the educational aspects of the undergraduates made possible by PIBID. For Silva (2015), the program promotes the interest of the student teachers in the course. Other studies have analyzed the influence of PIBID in structuring the teaching knowledge of its participants (Morais \& Ferreira, 2014; Sá \& Garritz, 2014) and adopt a qualitative methodology. In the exploratory analysis of studies related to PIBID, the studies are associated to teacher training, the production of teaching materials and reports of experiences (Passoni et al., 2012), suggesting that studies addressing student perceptions on the teaching practice of PIBID students are rare, mainly of their teaching knowledge (Freire \& Fernandez, 2014).

\section{Research Methodology}

\section{Context of the Research}

The PIBID students participating in this research were part of a subproject organized by a coordinator in the Chemistry teacher education program, two in-service Chemistry teachers (supervisors) and eleven pre-service teachers. In the subproject, the teaching proposals were associated to the Política Nacional de Resíduos Sólidos (PNRS, "National Policy of Solid Waste") (Brasil, 2010) and founded in the Science, Technology and Society (STS) approach and on experimental activities. During the implementation of the subproject, meetings were organized and conducted by the coordinator who, together with the pre-service teachers, defined the classroom objectives, the theoretical references to be studied and the inquiry questions to be chosen for each group of preservice teachers, which guided the planning of the teaching sequences. Then, in individual meetings with each group, the concepts, teaching strategies, methods of evaluation, among other aspects involved in the teaching sequences were defined. 
In this research, the teacher knowledge of five pre-service chemistry teachers were analyzed. For ethical reasons they will be referred to using fictitious names, Antônio, Melissa, Clara, Elder and Mateus. Over the course of a semester, Antônio and Melissa developed the topic "The inadequate disposal of automotive batteries" using the chemical concept of redox reactions, in a senior year of Educação de Jovens e Adultos ("Youths and Adults Education"). Elder, Clara and Mateus taught classes to sophomore year from secondary school, about the issue "Disposal of fluorescent bulbs in teaching electrochemistry".

\section{Quantitative Research}

This research used a quantitative approach. The reliability of the instrument was determined by analyzing the internal consistency through Cronbach's alpha. According to Diehl, quantitative research minimizes possible "[...] distortions of analysis and interpretation and allowing greater safety margin" (p.13, 2004).

The instrument used in this research was adapted from the one developed by Jang, Guan and Hsieh (2009) and translated by Girotto Júnior (2015). The instrument consists of four categories of statements: Subject Matter Knowledge (SMK), Instructional Representation and Strategies (IRS), Instructional Objective and Context (IOC) and Knowledge of Students' Understanding (KSU). SMK is related to student perceptions regarding their teachers knowledge of the topic in the context of the discipline. IRS aims to examine how the students understand the elements associated to the teaching strategies of their teachers including group discussions, experimental investigation, among others. The purpose of IOC is to understand how the students perceive the teacher's proposals and objectives in teaching, which encompasses knowledge of the context, the curriculum and class management. KSU is related to student perception regarding the methods of evaluation used by the teacher to evaluate them (Jang, Guan \& Hsieh, 2009). Each category had six options (Likert scale). The scale ranged as follows: 0 (I don't remember / I don't know), 1 (If it never happened in the teaching practice), 2 (If it seldom happened in the teaching practice), 3 (If it sometimes happened in the teaching practice), 4 (If it often happened in the teaching practice) and 5 (If it always happened in the teaching practice). The instrument also included an open question that allowed the respondent to talk about a learning difficulty or to make some comments on the pre-service teacher. The original test did not have the 0 (I don't remember / I don't know) option on the scale, which we included in this research. The adapted instrument used in this research consists of 28 statements and six options (appendix).

\section{Procedure}

The instrument was applied in a class where each pre-service teacher taught their lessons. The students who answered the instrument were those who attended classes during the school year, meaning we worked with a population of convenience, despite the understanding that the greater the number of respondents, the greater its variance (Bland \& Altman, 1997) and, consequently, that the number of participants influences the value of the Cronbach's Alpha calculated. As such, the instrument was answered by 70 students, with 45 from the sophomore year of regular Secondary School and 25 from the senior year of EJA (EJA, Youths and Adults Education). The instrument was answered by a total of seventy students from Secondary School and from $E J A$.

\section{Quantitative Data Analysis - Cronbach's Alpha}

In this research, Cronbach's Alpha was used to analyze the reliability of the instrument (Cronbach \& Shavelson, 2004; Leontitsis \& Pagge, 2007). In the literature, there is no agreement regarding the value of alpha in analyzing the reliability of an instrument. Along these lines, the lower limit of .7 is accepted and other studies accept .6 for exploratory research (Hair 
Keysy S. C. NOGUEIRA, Carmen FERNANDEZ. The reliability of an instrument to measure teacher knowledge from the perspective of learners in the context of PIBID

PROBLEMS

OF EDUCATION

IN THE $21^{\text {st }}$ CENTURY Vol. 76, No. 1,2018

Júnior, Black, Babin \& Anderson, 2009; Santos, 1999). Values lower than 0.6 indicate that the instrument has a low internal consistency, which can lead to incorrect conclusions about what it is supposed to measure (Hair Júnior, Black, Babin \& Anderson; Landis \& Koch, 1977; Malhotra, 2011; Vieira, 2009). The authors Freitas and Rodrigues (2005) suggest a classification for alpha values, presented in Table 1.

Table 1. Classification of the Cronbach's Alpha values and reliability.

\begin{tabular}{llllll}
\hline Reliability & Very low & Low & Moderate & High & Very High \\
\hline $\begin{array}{l}\text { Cronbach's Alpha } \\
\text { Value }\end{array}$ & $\alpha<.30$ & $.30 \leq \alpha<.60$ & $.60 \leq \alpha<.75$ & $.75 \leq \alpha<.90$ & $.90 \leq \alpha$ \\
\hline
\end{tabular}

In the present research, the coefficient was analyzed per individual sample, including the overall Cronbach's Alpha calculation for the entire instrument (considering all 28 statements) and by dimension (SMK, IRS, IOC and KSU). Moreover, calculations related to the exploratory analysis (mean, median and standard deviation) were carried out.

The analysis of the instrument was carried out separately for each pre-service tacher. Primarily, it will be presented the treatment of the data related to the percentage of respondents who answered each question that constituted the categories. Then, it will be presented the exploratory analysis for the five pre-service teachers and finally, the presentation and discussion related to the Cronbach's Alpha values and the validation of the instrument. The analysis is founded on the exploratory procedure and not the inferential procedure, meaning the set of data from the sample will not be used to generalize to a population (Bland \& Altman, 1997). The analysis of the open question of the instrument will not be presented here.

\section{Validity}

The validity of an instrument analyzes whether it is evaluating what it is meant to measure. There are no formal mathematical methods to analyze the validity of a instrument, despite some studies appealing to a statistical analysis of factorial design, which describes the correlation between variables. The factorial analysis is considered controversial due to its subjectivity (Bittencourt, Creutzberg, Rodrigues, Casartelli \& Freitas, 2011). As a result of this, researchers appeal to methods of reliability (Hora, Monteiro \& Arica, 2010). However, there is no reciprocity between the instrument being reliable and valid, since not every construct that is reliable is valid. On the other hand, every valid instrument can be reliable (Vieira, 2009). Various authors propose different methods of validation (Bittencourt, Creutzberg, Rodrigues, Casartelli \& Freitas, 2011; Vianna, 1976). Moron (1998) suggests the apparent validity of the content, criterion and construct. In this research, we only consider the validity of the content, which consists of an analysis of the content in the instrument by specialists from the area (Haynes, Richard \& Kubany, 1995).

\section{Research Results}

\section{Exploratory Analysis}

The pre-service teacher Antônio was in his freshman year in the PIBID teacher program and in the sixth semester of the teaching degree in chemistry. Antônio taught class in a secondary senior year class in EJA with 13 attending students. Table 2 gathers the percentages of the participants who completed the statements that constitute the categories Subject Matter Knowledge (SMK), Instructional Representation and Strategies (IRS), Instructional Objective and Context (IOC) and Knowledge of Students' Understanding (KSU). 
Keysy S. C. NOGUEIRA, Carmen FERNANDEZ. The reliability of an instrument to measure teacher knowledge from the perspective of learners in the context of PIBID

Table 2. Percentage of respondents who answered the instrument in each category - Antônio.

\begin{tabular}{|c|c|c|c|c|c|c|c|c|c|c|c|c|c|}
\hline \multirow[b]{2}{*}{ Statement } & \multicolumn{6}{|c|}{ Answers given (\%) } & \multirow[b]{2}{*}{ Statement } & \multicolumn{6}{|c|}{ Answers given (\%) } \\
\hline & 0 & 1 & 2 & 3 & 4 & 5 & & 0 & 1 & 2 & 3 & 4 & 5 \\
\hline SMK 1 & 0 & 0 & 0 & 15 & 38 & 46 & IOC 1 & 0 & 0 & 0 & 15 & 46 & 38 \\
\hline SMK 2 & 0 & 0 & 0 & 46 & 31 & 23 & IOC 2 & 0 & 0 & 0 & 8 & 23 & 69 \\
\hline SMK 3 & 0 & 0 & 0 & 38 & 23 & 38 & $10 C 3$ & 0 & 0 & 15 & 15 & 38 & 31 \\
\hline SMK 4 & 8 & 0 & 0 & 0 & 62 & 31 & IOC 4 & 0 & 0 & 8 & 38 & 46 & 8 \\
\hline SMK 5 & 0 & 0 & 0 & 23 & 54 & 23 & IOC 5 & 0 & 0 & 15 & 23 & 23 & 38 \\
\hline SMK 6 & 8 & 0 & 8 & 23 & 31 & 31 & IOC 6 & 8 & 0 & 8 & 15 & 46 & 23 \\
\hline SMK 7 & 0 & 0 & 8 & 0 & 54 & 38 & IOC 7 & 0 & 8 & 0 & 8 & 31 & 54 \\
\hline IRS 1 & 0 & 0 & 0 & 15 & 38 & 46 & KSU 1 & 0 & 0 & 15 & 31 & 23 & 31 \\
\hline IRS 2 & 0 & 8 & 8 & 8 & 54 & 23 & KSU 2 & 0 & 8 & 15 & 38 & 38 & 0 \\
\hline IRS 3 & 0 & 0 & 8 & 31 & 31 & 31 & KSU 3 & 8 & 8 & 0 & 31 & 46 & 8 \\
\hline IRS 4 & 0 & 0 & 8 & 15 & 8 & 69 & KSU 4 & 8 & 8 & 0 & 38 & 23 & 23 \\
\hline IRS 5 & 0 & 0 & 8 & 23 & 31 & 38 & KSU 5 & 0 & 0 & 8 & 8 & 54 & 31 \\
\hline IRS 6 & 0 & 0 & 0 & 38 & 62 & 0 & KSU 6 & 8 & 0 & 8 & 23 & 38 & 23 \\
\hline IRS 7 & 8 & 0 & 31 & 15 & 31 & 15 & KSU 7 & 0 & 0 & 15 & 15 & 31 & 38 \\
\hline
\end{tabular}

0 (I don't know), 1 (Never), 2 (Seldom), 3 (Sometimes), 4 (Often) and 5 (Always).

In general, the mean, median and standard deviation for the categories are reflected in the percentage of students who completed the questions that constituted the categories and their scales. These values are presented in Table 3.

Table 3. Mean and standard deviation values for each category referring to the answers about Antônio's classes.

\begin{tabular}{llll}
\hline Categories & Mean & Median & Standard deviation \\
\hline SMK & 3.98 & 4 & 0.99 \\
\hline IRS & 3.85 & 4 & 1.07 \\
\hline IOC & 3.98 & 4 & 1.04 \\
\hline KSU & 3.54 & 4 & 1.21 \\
\hline
\end{tabular}

Melissa also developed her activities in EJA during the semester. The student-teacher was in her freshman year of the teacher education course and of PIBID. The instrument was answered by 12 students, while one of the students did not want to answer the instrument for Melissa.

Primarily, the data were organized (Table 4) according to the percentage of respondents who completed one of the twenty-eight subcategories, in addition to the maximum and minimum values given. 
Keysy S. C. NOGUEIRA, Carmen FERNANDEZ. The reliability of an instrument to measure teacher knowledge from the perspective of learners in the context of PIBID

PROBLEMS

OF EDUCATION IN THE $21^{\text {st }}$ CENTURY Vol. 76, No. 1, 2018

Table 4. Percentage of respondents who answered the statements that constitute each category - Melissa.

\begin{tabular}{|c|c|c|c|c|c|c|c|c|c|c|c|c|c|}
\hline \multirow{2}{*}{$\begin{array}{l}\text { State- } \\
\text { ment }\end{array}$} & \multicolumn{6}{|c|}{ Answers given (\%) } & \multirow[b]{2}{*}{ Statement } & \multicolumn{6}{|c|}{ Answers given (\%) } \\
\hline & 0 & 1 & 2 & 3 & 4 & 5 & & 0 & 1 & 2 & 3 & 4 & 5 \\
\hline SMK 1 & 8.3 & 0 & 0 & 8.3 & 33.3 & 50 & IOC 1 & 0 & 0 & 8.3 & 25 & 33.3 & 33.3 \\
\hline SMK 2 & 0 & 0 & 8 & 33 & 17 & 42 & IOC 2 & 0 & 0 & 0 & 17 & 33 & 50 \\
\hline SMK 3 & 8 & 0 & 0 & 17 & 33 & 42 & $10 C 3$ & 0 & 0 & 17 & 17 & 33 & 33 \\
\hline SMK 4 & 0 & 0 & 0 & 17 & 8 & 75 & IOC 4 & 8 & 0 & 8 & 17 & 25 & 42 \\
\hline SMK 5 & 0 & 0 & 0 & 25 & 42 & 33 & IOC 5 & 8 & 8 & 8 & 8 & 33 & 33 \\
\hline SMK 6 & 0 & 0 & 8.3 & 25 & 33.3 & 33.3 & $10 C 6$ & 17 & 0 & 8 & 8 & 42 & 25 \\
\hline SMK 7 & 0 & 0 & 0 & 25 & 33 & 42 & $10 C 7$ & 0 & 0 & 8 & 17 & 42 & 33 \\
\hline IRS 1 & 0 & 0 & 8 & 25 & 25 & 42 & KSU 1 & 8 & 17 & 8 & 17 & 25 & 25 \\
\hline IRS 2 & 0 & 8 & 0 & 33 & 17 & 42 & KSU 2 & 0 & 8 & 8 & 25 & 25 & 33 \\
\hline IRS 3 & 0 & 0 & 8 & 8 & 50 & 33 & KSU 3 & 8 & 0 & 17 & 17 & 33 & 25 \\
\hline IRS 4 & 0 & 8 & 8 & 17 & 25 & 42 & KSU 4 & 0 & 8 & 8 & 17 & 33 & 33 \\
\hline IRS 5 & 8 & 0 & 8 & 17 & 33 & 33 & KSU 5 & 0 & 8 & 0 & 25 & 33 & 33 \\
\hline IRS 6 & 0 & 17 & 8 & 17 & 33 & 25 & KSU 6 & 8 & 17 & 0 & 8 & 25 & 42 \\
\hline IRS 7 & 8 & 8 & 8 & 25 & 25 & 25 & KSU 7 & 0 & 0 & 8 & 25 & 25 & 42 \\
\hline
\end{tabular}

0 (I don't know), 1 (Never), 2 (Seldom), 3 (Sometimes), 4 (Often) and 5 (Always)

The grouping of the values for mean, standard deviation and median are presented in Table 5 .

Table 5. Mean values and standard deviation for each category referring to the answers about Melissa's classes.

\begin{tabular}{llll}
\hline Category & Mean & Median & Standard deviation \\
\hline SMK & 4.09 & 4 & 1.07 \\
\hline IRS & 3.72 & 4 & 1.30 \\
\hline IOC & 3.80 & 4 & 1.30 \\
\hline KSU & 3.60 & 4 & 1.41 \\
\hline
\end{tabular}

The third pre-service teacher, Mateus, was in his sophomore year in the program PIBID and in the teacher education course. His classes in the partner school were given in two sophomore year classes in regular secondary school, which were usually held, due to the low attendance of the students in the teaching institution. Table 6 gathers the percentages of the participants who valued the statements that constitute the categories analyzed. 
Keysy S. C. NOGUEIRA, Carmen FERNANDEZ. The reliability of an instrument to measure teacher knowledge from the perspective of learners in the context of PIBID

Table 6. Percentage of respondents who valued the statements, that constitute each category - Mateus.

\begin{tabular}{|c|c|c|c|c|c|c|c|c|c|c|c|c|c|}
\hline \multirow{2}{*}{$\begin{array}{l}\text { State- } \\
\text { ment }\end{array}$} & \multicolumn{6}{|c|}{ Answers given (\%) } & \multirow{2}{*}{$\begin{array}{l}\text { State- } \\
\text { ment }\end{array}$} & \multicolumn{6}{|c|}{ Answers given (\%) } \\
\hline & 0 & 1 & 2 & 3 & 4 & 5 & & 0 & 1 & 2 & 3 & 4 & 5 \\
\hline SMK 1 & 0 & 0 & 0 & 20 & 0 & 80 & IOC 1 & 0 & 0 & 6.6 & 6.6 & 26.6 & 60 \\
\hline SMK 2 & 0 & 6.6 & 0 & 20 & 60 & 13.3 & IOC 2 & 0 & 0 & 6.6 & 33.3 & 33.3 & 26.6 \\
\hline SMK 3 & 0 & 0 & 0 & 13.3 & 66.6 & 20 & $10 C 3$ & 0 & 0 & 0 & 13.3 & 33.3 & 53.3 \\
\hline SMK 4 & 0 & 0 & 6.6 & 13.3 & 6.6 & 73.3 & IOC 4 & 0 & 0 & 6.6 & 26.6 & 33.3 & 33.3 \\
\hline SMK 5 & 0 & 0 & 6.6 & 6.6 & 40 & 46.6 & IOC 5 & 0 & 0 & 6.6 & 26.6 & 26.6 & 40 \\
\hline SMK 6 & 6.6 & 0 & 6.6 & 33.3 & 20 & 33.3 & IOC 6 & 0 & 0 & 13.3 & 6.6 & 26.6 & 53.3 \\
\hline SMK 7 & 0 & 0 & 6.6 & 6.6 & 53.3 & 33.3 & IOC 7 & 0 & 0 & 6.6 & 6.6 & 13.3 & 73.3 \\
\hline IRS 1 & 0 & 0 & 0 & 20 & 13.3 & 66.6 & KSU 1 & 20 & 6.6 & 13.3 & 26.6 & 20 & 13.3 \\
\hline IRS 2 & 0 & 40 & 0 & 33.3 & 6.6 & 20 & KSU 2 & 6.6 & 0 & 6.6 & 53.3 & 13.3 & 20 \\
\hline IRS 3 & 0 & 13.3 & 0 & 13.3 & 0 & 73.3 & KSU 3 & 0 & 0 & 20 & 26.6 & 26.6 & 26.6 \\
\hline IRS 4 & 0 & 6.6 & 0 & 6.6 & 6.6 & 80 & KSU 4 & 6.6 & 0 & 13.3 & 33.3 & 20 & 26.6 \\
\hline IRS 5 & 0 & 6.6 & 6.6 & 26.6 & 26.6 & 33.3 & KSU 5 & 0 & 0 & 6.6 & 20 & 6.6 & 66.6 \\
\hline IRS 6 & 0 & 6.6 & 6.6 & 33.3 & 13.3 & 40 & KSU 6 & 0 & 0 & 0 & 13.3 & 40 & 46.6 \\
\hline IRS 7 & 0 & 13.3 & 66.6 & 6.6 & 6.6 & 6.6 & KSU 7 & 0 & 0 & 6.6 & 13.3 & 6.6 & 73.3 \\
\hline
\end{tabular}

0 (I don't know), 1 (Never), 2 (Seldom), 3 (Sometimes), 4 (Often) and 5 (Always)

The results of the instrument answered by the students for Mateus, regarding the exploratory analysis are presented in Table 7.

Table 7. Mean and standard deviation values for each category referring to the answers about Mateus' classes.

\begin{tabular}{llll}
\hline Categories & Mean & Median & Standard deviation \\
\hline SMK & 4.12 & 4 & 0.98 \\
\hline IRS & 3.65 & 4 & 1.45 \\
\hline IOC & 4.18 & 4 & 0.94 \\
\hline KSU & 3.74 & 4 & 1.35 \\
\hline
\end{tabular}

The PIBID pre-service teacher Clara was in her freshman year of the chemistry teaching education course and also in PIBID. She worked together with Mateus and Elder. Table 8 presents the percentages of participants who completed the questions that constituted the categories analyzed. 
Keysy S. C. NOGUEIRA, Carmen FERNANDEZ. The reliability of an instrument to measure teacher knowledge from the perspective of learners in the context of PIBID

PROBLEMS

OF EDUCATION IN THE $21^{\text {st }}$ CENTURY Vol. 76, No. 1, 2018

Table 8. Percentage of respondents who valued the statements, which constituted each category - Clara.

\begin{tabular}{|c|c|c|c|c|c|c|c|c|c|c|c|c|c|}
\hline \multirow[b]{2}{*}{ Statement } & \multicolumn{6}{|c|}{ Answers given (\%) } & \multirow[b]{2}{*}{ Statement } & \multicolumn{6}{|c|}{ Answers given (\%) } \\
\hline & 0 & 1 & 2 & 3 & 4 & 5 & & 0 & 1 & 2 & 3 & 4 & 5 \\
\hline SMK 1 & 0 & 6.6 & 0 & 20 & 26.6 & 46.6 & IOC 1 & 0 & 0 & 6.6 & 13.3 & 33.3 & 46.6 \\
\hline SMK 2 & 0 & 6.6 & 6.6 & 6.6 & 26.6 & 53.3 & IOC 2 & 0 & 0 & 6.6 & 6.6 & 26.6 & 60 \\
\hline SMK 3 & 0 & 6.6 & 0 & 6.6 & 26.6 & 60 & $10 C 3$ & 0 & 0 & 6.6 & 20 & 13.3 & 60 \\
\hline SMK 4 & 0 & 6.6 & 6.6 & 6.6 & 13.3 & 66.6 & IOC 4 & 0 & 0 & 6.6 & 26.6 & 20 & 46.6 \\
\hline SMK 5 & 0 & 6.6 & 0 & 13.3 & 26.6 & 53.3 & IOC 5 & 0 & 0 & 20 & 13.3 & 13.3 & 53.3 \\
\hline SMK 6 & 0 & 6.6 & 13.3 & 6.6 & 26.6 & 46.6 & $10 C 6$ & 0 & 0 & 6.6 & 0 & 33.3 & 60 \\
\hline SMK 7 & 0 & 6.6 & 0 & 13.3 & 20 & 60 & IOC 7 & 0 & 0 & 13.3 & 0 & 40 & 46.6 \\
\hline IRS 1 & 0 & 6.6 & 13.3 & 6.6 & 40 & 33.3 & KSU 1 & 0 & 0 & 6.6 & 33.3 & 20 & 40 \\
\hline IRS 2 & 0 & 20 & 6.6 & 13.3 & 26.6 & 33.3 & KSU 2 & 26.6 & 0 & 6.6 & 20 & 20 & 26.6 \\
\hline IRS 3 & 0 & 0 & 6.6 & 13.3 & 13.3 & 66.6 & KSU 3 & 0 & 0 & 13.3 & 0 & 53.3 & 33.3 \\
\hline IRS 4 & 0 & 0 & 6.6 & 0 & 26.6 & 66.6 & KSU 4 & 0 & 0 & 6.6 & 0 & 26.6 & 66.6 \\
\hline IRS 5 & 0 & 0 & 13.3 & 20 & 20 & 46.6 & KSU 5 & 0 & 0 & 6.6 & 6.6 & 26.6 & 60 \\
\hline IRS 6 & 0 & 0 & 13.3 & 20 & 33.3 & 33.3 & KSU 6 & 0 & 0 & 6.6 & 6.6 & 33.3 & 53.3 \\
\hline IRS 7 & 0 & 13.3 & 13.3 & 6.6 & 26.6 & 40 & KSU 7 & 0 & 0 & 6.6 & 0 & 26.6 & 66.6 \\
\hline
\end{tabular}

0 (I don't know), 1 (Never), 2 (Seldom), 3 (Sometimes), 4 (Often) and 5 (Always)

The results of the instrument answered by the students for Clara, regarding the exploratory analysis are presented in Table 9.

Table 9. Mean and standard deviation values for each category referring to the answers about Clara's classes.

\begin{tabular}{llll}
\hline Categories & Mean & Median & Standard deviation \\
\hline SMK & 4.17 & 5 & 1.18 \\
\hline IRS & 3.96 & 4 & 1.23 \\
\hline IOC & 4.23 & 5 & 1 \\
\hline KSU & 4.09 & 4 & 1.23 \\
\hline
\end{tabular}

Similarly to Clara and Melissa, the PIBID pre-service teacher Elder was in his freshman year of chemistry teacher education course. He entered PIBID in the second semester of the teacher education course. In his initial trajectory in the context of the beginning teacher program, he taught classes on the redox content. Table 10 presents the percentage of students who answered the questions that constitute each category of teacher knowledge. 
Keysy S. C. NOGUEIRA, Carmen FERNANDEZ. The reliability of an instrument to measure teacher knowledge from the perspective of learners in the context of PIBID

Table 10. Percentage of respondents who valued the statements that constitute each category - Elder.

\begin{tabular}{|c|c|c|c|c|c|c|c|c|c|c|c|c|c|}
\hline \multirow[b]{2}{*}{ Statement } & \multicolumn{6}{|c|}{ Answers given (\%) } & \multirow{2}{*}{$\begin{array}{l}\text { State- } \\
\text { ment }\end{array}$} & \multicolumn{6}{|c|}{ Answers given (\%) } \\
\hline & 0 & 1 & 2 & 3 & 4 & 5 & & 0 & 1 & 2 & 3 & 4 & 5 \\
\hline SMK 1 & 0 & 6.6 & 6.6 & 13.3 & 13.3 & 60 & IOC 1 & 0 & 0 & 6.6 & 26.6 & 46.6 & 20 \\
\hline SMK 2 & 0 & 0 & 6.6 & 20 & 33.3 & 40 & IOC 2 & 0 & 0 & 6.6 & 13.3 & 26.6 & 53.3 \\
\hline SMK 3 & 0 & 0 & 13.3 & 6.6 & 20 & 60 & $10 C 3$ & 0 & 0 & 20 & 13.3 & 13.3 & 53.3 \\
\hline SMK 4 & 0 & 0 & 6.6 & 13.3 & 26.6 & 53.3 & IOC 4 & 0 & 6.6 & 6.6 & 20 & 33.3 & 53.3 \\
\hline SMK 5 & 0 & 0 & 6.6 & 20 & 26.6 & 46.6 & IOC 5 & 0 & 0 & 20 & 6.6 & 33.3 & 40 \\
\hline SMK 6 & 0 & 6.6 & 13.3 & 6.6 & 26.6 & 46.6 & 1006 & 6.6 & 0 & 6.6 & 26.6 & 20 & 40 \\
\hline SMK 7 & 0 & 0 & 6.6 & 6.6 & 20 & 66.6 & IOC 7 & 6.6 & 6.6 & 0 & 6.6 & 46.6 & 33.3 \\
\hline IRS 1 & 6.6 & 0 & 13.3 & 13.3 & 40 & 26.6 & KSU 1 & 0 & 0 & 26.6 & 20 & 13.3 & 40 \\
\hline IRS 2 & 0 & 13.3 & 6.6 & 26.6 & 20 & 33.3 & KSU 2 & 6.6 & 6.6 & 6.6 & 26.6 & 26.6 & 26.6 \\
\hline IRS 3 & 0 & 0 & 20 & 0 & 40 & 40 & KSU 3 & 0 & 6.6 & 0 & 13.3 & 40 & 40 \\
\hline IRS 4 & 0 & 0 & 6.6 & 20 & 26.6 & 46.6 & KSU 4 & 0 & 13.3 & 0 & 20 & 33.3 & 33.3 \\
\hline IRS 5 & 0 & 6.6 & 6.6 & 6.6 & 33.3 & 46.6 & KSU 5 & 0 & 0 & 0 & 26.6 & 33.3 & 40 \\
\hline IRS 6 & 6.6 & 0 & 13.3 & 6.6 & 33.3 & 40 & KSU 6 & 0 & 0 & 0 & 20 & 46.6 & 33.3 \\
\hline IRS 7 & 0 & 6.6 & 20 & 20 & 13.3 & 40 & KSU 7 & 0 & 0 & 0 & 20 & 20 & 60 \\
\hline
\end{tabular}

0 (I don’t know), 1 (Never), 2 (Seldom), 3 (Sometimes), 4 (Often) and 5 (Always)

Table 11 presents the percentage of students who valued the statements that constitute each category of teacher knowledge.

Table 11. Mean and standard deviation values for each category referring to the answers about Elder's classes.

\begin{tabular}{llll}
\hline Categories & Mean & Median & Standard deviation \\
\hline SMK & 4.18 & 5 & 1.07 \\
\hline IRS & 3.82 & 4 & 1.28 \\
\hline IOC & 3.90 & 4 & 1.19 \\
\hline KSU & 3.93 & 4 & 1.13 \\
\hline
\end{tabular}

\section{Reliability - Cronbach's Alpha}

The measures of exploratory statistical analysis did not indicate the reliability of the instrument. As such, it was calculated Cronbach's Alpha to ensure the reliability of the answers given by the students regarding their perceptions of the PCK of the pre-service teachers. In Table 12, the values of the alpha coefficient were compiled for the entire instrument and by category. 
Keysy S. C. NOGUEIRA, Carmen FERNANDEZ. The reliability of an instrument to measure teacher knowledge from the perspective of learners in the context of PIBID

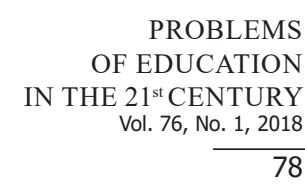

Table 12. Cronbach's Alpha values for the entire instrument and by category.

\begin{tabular}{llllll}
\hline \multirow{2}{*}{$\begin{array}{l}\text { Pibid students } \\
\text { (pre-service } \\
\text { teachers) }\end{array}$} & Alpha values & \multicolumn{3}{l}{} \\
\cline { 2 - 6 } & Instrument & Category & & IOC & KSU \\
\cline { 2 - 6 } Antônio & .92 & SMK & IRS & .72 & .83 \\
\hline Melissa & .95 & .77 & .82 & .77 & .91 \\
\hline Mateus & .95 & .85 & .84 & .89 & .77 \\
\hline Clara & .96 & .97 & .82 & .89 & .84 \\
\hline Elder & .94 & .84 & .86 & .83 & .80 \\
\hline
\end{tabular}

\section{Validation}

In this research, the validation of the content was done by 3 graduate students who research chemistry teacher knowledge.

\section{Discussion}

\section{Exploratory Analysis}

Data analyses of the Table 2, in the SMK 1 question "My teacher knows the content he/she is teaching", for $46 \%$, Antônio always demonstrated proficiency in the redox subject that he was teaching and, for another $31 \%$, the student-teacher frequently explained the impact of this subject on society (SMK 6). In the item IRS 7 "My teacher uses multimedia or technology to express the concepts", Antônio rarely (31\%) used technology as a strategy to develop concepts. However, the same percentage of students believed that Antônio frequently used these resources. Despite the students recognize that Antônio used different approaches, the use of strategies involving media and technology perhaps needs to be improved. Regarding the category IOC 2 "My teacher provides an appropriate interaction or good atmosphere" for $69 \%$ of the studentes, Antônio always provided interaction with the students and, consequently, made the classroom space conducive to a social atmosphere. Upon contrasting this percentage with another similar question from the IRS 4 category "My teacher provides opportunities for me to express my views during class", it was observed in the paragraph above that the same percentage is obtained from students who answered that this atmosphere always existed in the student-teacher classes, indicating that the items involved in these questions are correlated.

In the item KSU 6 "My teacher's assignments facilitate my understanding of the subject", in the view of $38 \%$ of the class, the use of a determined methodology often facilitated the understanding of the subject, while for $23 \%$, it always happened, and, for another $23 \%$, it sometimes occurred in the teaching practice. Perhaps it is difficult for the students to understand the extent of the activities developed by Antônio before going into the classroom and, consequently, to understand that one of the results of these tasks is class preparation.

The results presented in Table 3, the mean values found for the categories do not have significant differences, suggesting that the students marked primarily scale 4 (Frequently happened in the teaching practice). In relation to the standard deviation, the category with the lowest value was the SMK and that with the highest value is KSU. The standard deviation values higher than one indicate that the students did not consistently answer the questions that constituted the categories. On the other hand, a value lower than one means that the groups marked mainly two scales, revealing consistent student perceptions. 
Based on the exploratory analysis, it was understood that, according to student perceptions, Antônio frequently (scale 4) demonstrated knowing the concepts that he taught, enabling the students to understand the objectives of his classes, the strategies that helped them in teaching and learning the specific subject, in addition to demonstrating an understanding of the difficulties, limitations and needs of his students in relation to the specific subject.

Upon analyzing the data for Table 4, in the subcategory SMK 1 "My teacher knows the content of teaching", according to $50 \%$ of the students from EJA, Melissa always demonstrated knowledge of the content, while 8\% answered I don't remember/I don't know. In SMK 4 "My teacher selects the appropriate content for students" for 75\% of the students, the studentteacher always adequately chose the concepts. On the other hand, 25\% answered sometimes and for another 25\% Melissa frequently used adequate examples to teach (IRS 1). In relation to using analogies in the student-teacher classes (IRS 2), for $42 \%$ of the students, they were always in Melissa's classes, while for another 33\%, it sometimes occurred in her practice, which generally means that the students did not always observe Melissa using analogies in her classes.

In relation to the IOC 1 subcategory "My teacher makes me clearly understand objectives of this course" for $8 \%$ rarely, 25\% sometimes, 33\% frequently, meaning that for $66 \%$ of the students, Melissa did not always make her educational objectives clear. When questioned on IOC 6 "My teacher copes with our classroom context appropriately" in the perspective of students $17 \%$ answered I don't remember/I don't know, $8 \%$ seldom, 8\% sometimes and $42 \%$ answered frequently. These values lead to the inference that the students did not have a homogeneous perception of how Melissa coped with the class.

In KSU 1 “My teacher realizes students 'prior knowledge before class", for 25\%, Melissa always checked their previous knowledge, while the perception for $25 \%$ was frequently. By contrast, $8 \%$ answered I don't remember/I don't know, 17\% never happened in practice, $8 \%$ rarely happened and for $17 \%$, sometimes.

In the Table 5, the standard deviation values for the four categories are higher than 1, which means that the students did not have a homogeneous perception of the statements constituting SMK, IRS, IOC and KSU. The values of the means are very similar, which was reflected in a median of scale 4 (frequently). These data suggest that in the students' perception, Melissa frequently accessed during her classes the knowledge related to the redox content and to teaching strategies, among others. The standard deviation values for the four categories are higher than 1, suggesting that the students had different perceptions for the statements constituting SMK, IRS, IOC and KSU. The mean values are very similar, which reflected in a median of 4 (If it happened frequently in the teaching practice), which means that in the perception of the group, Melissa frequently accessed during her classes the knowledge related to the redox content and to teaching strategies, among others.

According to the data presented in Table 6, in question SMK 1 "My teacher knows the content of teaching", for $80 \%$ of the class, Mateus always seemed to dominate the content on electrochemistry that he taught. Perhaps knowing that the PIBID student-teacher dominated the subject, when questioned SMK 3 "My teacher knows how theories or principles of the subject have been developed" for $66 \%$, the pre-service teacher often demonstrated knowing them. In relation to the use of analogies (IRS 2), $40 \%$ of the students marked scale 1 (If it never happened in the teaching practice) which means that they did not perceive the use of this strategy. On the other hand, for $66.66 \%$ of the respondents, the PIBID student-teacher gave examples (IRS 1) that made the learning easier.

In relation to IOC 2 "My teacher provides an appropriate interaction or good atmosphere" the class did not have a hegemonic perception, since, for $6.66 \%$ it rarely happened, for $33.33 \%$ sometimes, for $33.33 \%$ often and, for only $26.66 \%$ Mateus was always able to implement a good atmosphere for interpersonal development. However, for $70 \%$ of the students, the PIBID student-teacher always promoted dynamic and active teaching (IOC 7).

The students' perception of the knowledge of the students' understanding reveals that only $13.33 \%$ indicated that Mateus always demonstrated his prior knowledge (SMK 1) Regarding 
Keysy S. C. NOGUEIRA, Carmen FERNANDEZ. The reliability of an instrument to measure teacher knowledge from the perspective of learners in the context of PIBID

\section{PROBLEMS \\ OF EDUCATION \\ IN THE $21^{\text {st }}$ CENTURY Vol. 76, No. 1, 2018 \\ 80}

the evaluation, in question KSU 7 "My teacher 's tests help me realize the learning situation", for $73.33 \%$, they always contributed to the students' understanding the electrochemistry concepts that formed the foundation of Mateus' classes. In relation to the teaching approaches in the classes of the PIBID pre-service teacher's, when they analyzed question KSU 5 "My teacher uses different approaches (questions, discussion, etc.) to find out whether I understand", 66.6\% of the students were able to identify the various teaching approaches and strategies that involved teaching the specific content.

In the Table 7 IRS and KSU categories, the standard deviation is higher than 1, which reveals that the group of students had a more heterogeneous perception about the knowledge involving teaching strategies and the students' knowledge in the classes taught by Mateus. On the other hand, it was observed a homogeneity in the answers for the statements from the SMK and IOC categories, suggesting that the class had a similar perception of the statements that constituted Mateus' knowledge in relation to the content, the class and his teaching proposals.

In her trajectory in PIBID, Clara helped the students with their doubts in relation to the chemistry content presented by Elder and Mateus. According to the results of Table 8, when the students were questioned regarding SMK 2 "My teacher explains clearly the content of the subject" and SMK 5 "My teacher knows the answers to the questions that we ask about the subject", the same percentage of students, $53.3 \%$, indicated that Clara was always able to explain their doubts and knew the electrochemistry content. Perhaps this perception of the students was a reflection of the PIBID student-teacher providing space to express their points of view (IRS 4) according to $66.6 \%$ of the students. On the other hand, for $26.6 \%$ of the students, Clara did not previously know about students' difficulties regarding electrochemistry (KSU 2).

In relation to the values of the exploratory analysis (Table 9), the standard deviation was higher than 1 for the SMK, IRS and IOC Categories, revealing an inconsistent perception of the students about this knowledge in the PCK of the PIBID pre-service teacher's. On the other hand, in the IOC category, which represented knowledge related to the strategies for teaching the content, the students demonstrated more similar perceptions.

The categories of teacher knowledge presented a standard deviation higher than or equal to one, which leads us to infer that the students had a more heterogeneous view on the questions that constituted the categories of Clara's knowledge.

Acording to the results of Table 10 in category SMK 1 "My teacher knows the content he/ she is teaching" for $60 \%$ of the students, Elder had knowledge about redox reactions. When the students analyzed the examples chosen by the PIBID student-teacher to explain the concepts (IRS 1), for $40 \%$ of the students, the examples often made it easier to understand the concepts taught. For $40 \%$ of the class, the PIBID student-teacher always had an adequate relation with the class (IOC 5), while for $20 \%$ of the class, it happened rarely.

In statement KSU 2 "My teacher knows students' learning difficulties of subject", for $26 \%$ of the students, the PIBID student-teacher was sometimes, often and always aware of his limitations with the redox subject. These data suggest that Elder needs to improve his understanding of the students' learning difficulties regarding the concepts he teaches.

The standard deviation values presented in Table 11 for the four categories raised a diverging view of the students on Elder's teaching knowledge in relation to redox reactions, students' difficulties, teaching strategies, the context, among others.

\section{Reliability - Cronbach's Alpha}

The results presented in Table 12 for Alpha from pre-service teachers were: .92 (Antônio), .95 (Melissa), .95 (Mateus), .96 (Clara) and .94 (Elder) reveal that the set of answers in the instrument used presented reliable answers and, consequently, very good internal consistency. The literature points out that the reliability of an instrument can present very good consistency in relation to the context. From this, one can infer that the degree of correlation between the statements that constitute each category had a good correlation as a result of the alpha values, 
since the number of statements in the instrument could result in an increase in the consistency of the scale used (Krus \& Helmstadter, 1993; Streiner, 2003). For Vieira (2009), when the alpha is calculated item by item, as was done in this research, there is a decline or improvement in the overall consistency, when a determined item is important or not in the instrument.

The calculation of the alpha coefficient for each of the dimensions (SMK, IRS, IOC and KSU) are also a consequence of this. The values for the four dimensions of teacher knowledge are higher than .6, which suggests that the instrument as a whole presents a good correlation between the categories. Moreover, the categories can be implemented separately if the researcher wished to do so. However, it was considered more pertinent to use it as a whole, as done in this research, since there are statements in each category that were related to the other categories, when considering its individual characteristics.

Overall, the reliability calculated for the instrument and analyzed for each participant revealed that the instrument is reliable and produces stable and consistent measurements, meaning that the instrument is reliable when used in the context of early teacher training.

\section{Validation}

Since the graduate students' analyses were effective, some commented that the statements in the categories were clear. On the other hand, others believe that certain questions bring up concepts that perhaps the students cannot understand, such as, for example, what the prior knowledge of the students is, analogies and methodologies. It is worth noting that, upon applying this instrument, these terms were explained to the students. Another suggestion would be to apply the instrument and change the order of the statements of each category. It is worth pointing out that this was not done in the present research.

\section{Conclusions}

The aim of this research was to evaluate the reliability of the instrument which measures teacher knowledge, in the context of PIBID and, consequently, whether the instrument could be used to measure the teacher's knowledge in pre-service teacher, based on student perspectives.

The values found for the Cronbach's Alpha allow us to conclude that the instrument applied is reliable regarding students' perceptions of the teaching knowledge of the PIBID preservice teacher's. Therefore, the instrument can be used in contexts of early teacher training and reveal to these subjects the specific components of professional knowledge of the preservice teachers that the students did not perceive. This information can be valuable for preservice teachers and can influence the planning and implementation process of classes, as well as student learning. It was believed the instrument can be used in research related to preservice teachers and continued teacher training, such that these professionals can reflect on their practice, based on their students' perceptions, because in the previous researches in which they were applied the instrument involved analysis of teacher knowledge in the university professors and experienced teachers.

In general, the purpose of this research was reached, because it was possible to assess the reliability of an instrument that measures teacher knowledge in the context of pre-service teachers. The future goal of the research is to adopt the instrument in activities developed by the pre-service teachers so that their planning of the didactic sequences contemplate the four SMK, IRS and IOC categories of the instrument. In addition, our intention is to apply the instrument to evaluate the teacher knowledge of pre-service chemistry teachers through the establishment of partnerships with researchers of the teaching area linked to other universities in the city of São Paulo. We believe that the adoption of this instrument in several stages of the education of undergraduates may promote reflective processes that contribute to the continuous professional development of these future professionals. 
Keysy S. C. NOGUEIRA, Carmen FERNANDEZ. The reliability of an instrument to measure teacher knowledge from the perspective of learners in the context of PIBID

\section{PROBLEMS \\ OF EDUCATION \\ IN THE $21^{\text {st }}$ CENTURY \\ Vol. 76, No. 1,2018 \\ Acknowledgment}

The author thanks for financial support the research group conducted by Brazilian government agencies FAPESP (Process N. 2013/07937-8 and 2016/08677-8).

\section{References}

Bittencourt, H. R., Creutzberg, M., Rodrigues, A. C. M., Casartelli, A. O., \& Freitas, A. L. S. (2011). Desenvolvimento e validação de um instrumento para avaliação de disciplinas na educação superior [Development and validation of an instrument for the evaluation of subjects in higher education]. Estudos em Avaliação Educional, 22 (48), 91-114.

Brasil. (2010). Lei $n^{\circ}$ 12.305. de 2 de agosto de 2010. Politica Nacional dos Resíduos Sólidos (PNRS) [National Solid Waste Policy]. Retrieved 04/10/2017, from http://www.planalto.gov.br/ccivil_03/ ato2007-2010/2010/lei/112305.htm

Bland, J. M., \& Altman, D. G. (2012). Cronbach's alpha. British Medical Journal, 314 (7080), 314-572.

Braibante, M. E. F., \& Wolmann, E. M. A. (2012). Influência do PIBID na Formação dos Acadêmicos de Química Licenciatura da UFSM [Influence of PIBID on the education of chemistry undergraduates at UFSM]. Quimica Nova na Escola, 34 (4), 167-172.

Canan, S. R. (2012). PIBID: Promoção e valorização da formação docente no âmbito da Política Nacional de Formação de Professores [PIBID: Promotion and recognition of teacher training within the framework of the national teacher training policy]. Revista Brasileira de Pesquisa sobre a Formação de Professores, 4 (6), 24-43.

Criua, R., \& Marian, A. (2014). The influence of students' perception of pedagogical content knowledge on self-efficacy in self-regulating learning in training of future teachers. Procedia - Social and Behavioral Sciences, 142, 673-678.

Cronbach, L. J., \& Shavelson, R. J. (2004). My current thoughts on coefficient alpha and successor procedures. Educational and Psychological Measurement, 64 (3), 391-418.

Diehl, A. A. (2004). Pesquisa em ciências sociais aplicadas: métodos e técnicas [Research methodology: Methods and techniques]. São Paulo: Prentice Hall.

Felício, H. M. S. (2014). O PIBID como "terceiro espaço" de formação inicial de professores [The PIBID as the "third space" in the initial formation of teachers]. Revista Diálogo Educacional, 14 (42), $415-434$.

Fernandez, C. (2014). Knowledge base for teaching and Pedagogical Content Knowledge (PCK): some useful models and implications for teachers training. Problems of Education in the 21st Century, $60(1), 79-100$.

Fernandez, C. (2015). Revisitando a base de conhecimentos e o conhecimento pedagógico do conteúdo (pck) de professores de ciências [Revisiting the knowledge base and science teachers' pedagogical content knowledge]. Revista Ensaio, 17 (2), 500-528.

Freire, L. I. F., \& Fernandez, C. (2014). Professores novatos de química e o desenvolvimento do PCK de oxidorredução: Influências da formação inicial [Novice chemistry teachers and the development of PCK of oxidation-reduction: Influence of initial tranning]. Educación Química, 25 (3), 312324.

Gatti, B. A., Barreto, E., \& André, M. E. D. A. (2011). Politicas docentes no Brasil: Um estado da arte [Teacher policies in Brazil: A state of the art]. Brasília: UNESCO.

Girotto Júnior, G. (2015). Análise do conhecimento pedagógico do conteúdo de professores de Química a partir da perspectiva do educando [Analysis of Pedagogical Content Knowledge of Chemistry teachers from the student's perspective] (doctoral dissertation, University of São Paulo, São Paulo, Brazil). Retrieved from http://www.teses.usp.br/teses/disponiveis/81/81132/tde-17122015114606/pt-br.php

Grossman, P. (1990). The making of a teacher: teacher knowledge and teacher education. New York: Teachers College Press. 
Hair Júnior, A., Black, W. C., Babin, B. J., \& Anderson, R. E. (2009). Multivariate data analysis. 7. Ed. New Jersey: Prentice Hall.

Halim, L., \& Abdullah, S. I. S. S. (2014). Students' perceptions of their science teachers' pedagogical content knowledge. Journal of Science Education and Technology, 23, 227-237.

Haynes, S. N., Richard, D. C. S., \& Kubany, E. S. (1995). Content validity in psychological assessment: A functional approach to concepts and methods. Psychological Assessment, 7 (3), 238-247.

Hora, H. R. M., Monteiro, G. T. R., \& Arica, J. (2010). Confiabilidade em Questionários para Qualidade: Um Estudo com o Coeficiente Alfa de Cronbach [Reliability in questionnaires for quality: A study with Cronbach's Alpha coefficient]. Produto \& Produção, 11 (2), 85-103.

Jang, S. J. (2011). Assessing college students' perceptions of a case teacher's pedagogical content knowledge using a newly developed instrument. Higher Education, 61 (6), 663-678.

Jang, S. J., Guan, S. Y., \& Hsieh, H. F. (2009). Developing an instrument for assessing college students' perceptions of teachers' pedagogical content knowledge. Procedia Social and Behavioral Sciences, 1 (1), 596-606.

Kirschner, S., Borowski, A., Fischer, H. E., Gess-Newsome, J., \& Von Aufschnaiter, C. (2016). Developing and evaluating a paper-and-pencil test to assess components of physics teachers' pedagogical content knowledge. International Journal of Science Education, 38 (8), 1343-1372.

Kleickmann, T., Richter, D., Kunter, M., Elsner, J., Besser, M., Krauss, S., \& Baumert, J. (2013). Teachers' content knowledge and pedagogical content knowledge: The role of structural differences in teacher education. Journal of Teacher Education, 64 (1), 90-106.

Krus, D. J., \& Helmstadter, G. C. (1993). The problem of negative reliabilities. Educational and Psychological Measurement, 53, 643-650.

Landis, J. R., \& Koch, G. G. (1977). The measurement of observer agreement for categorical data. Biometrics, 33, 159-174.

Leontitsis, A., \& Pagge, J. (2007). A simulation approach on Cronbach's alpha statistical significance. Mathematics and Computers in Simulation, 73, 336-340.

Magnusson, S., Krajcik, L., \& Borko, H. (1999) Nature, sources and development of pedagogical content knowledge. In: Gess-Newsome, J., \& Lederman, N. G. (Eds.). Examining pedagogical content knowledge: the construct and its implications for science education. Dordrecht, The Netherlands: Kluwer Academics, 95-132.

Morais, J. K. C., \& Ferreira, M. A. S. (2014). Profissionalização docente: Construindo saberes a partir da prática no PIBID [Teacher professionalization: Constructing knowledge based on practice in PIBID]. Revista Holo, 5, 112-120.

Moron. M. A. M. (1998). Concepção, desenvolvimento e validação de instrumentos de coleta de dados para estudar a percepção do processo decisório e as diferenças culturais [Design, development and validation of data collection instruments to study the perception of decision making and cultural differences] (doctoral dissertation, Federal University of Rio Grande do Sul, Porto Alegre, Brazil). Retrieved from http://www.lume.ufrgs.br/handle/10183/2070.

Passoni, L. C., Vega, M. R., Giacomini, R., Barreto, A. M. P., Soares, J. S. C., Crespo, L. C., \& NEY, M. R. G. (2012). Relatos de Experiências do Programa Institucional de Bolsa de Iniciação à Docência no Curso de Licenciatura em Química da Universidade Estadual do Norte Fluminense [Accouts of experiences of the institutional program of scholarship initiation to teaching in the course of degree in chemistry of the state university of North Fluminense]. Química Nova na Escola, 34 (4), 201-209.

Peterson, K. D., Wahlquist, C., \& Bone, K. (2000). Student surveys for school teacher evaluation. Journal of Personnel Evaluation in Education, 14 (2), 135-153.

Ribeiro, L. A., \& Nogueira, E. G. D. (2016). O desenvolvimento profissional docente e o PIBID: Influências do programa desvelada por seus egressos [Professional development and PIBID: Program revealed for their graduates]. Práxis Educacional, 12 (21), 45-74.

Rollnick, M., \& Mavhunga, E. (2014). PCK of teaching electrochemistry in chemistry teachers: A case in Johannesburg, Gauteng Province, South Africa. Educación Química, 25 (3), 354-362. 
Keysy S. C. NOGUEIRA, Carmen FERNANDEZ. The reliability of an instrument to measure teacher knowledge from the perspective of learners in the context of PIBID

PROBLEMS

OF EDUCATION

IN THE $21^{\text {st }}$ CENTURY Vol. 76, No. 1, 2018

Sá, L. P., \& Garritz, A. (2014). O conhecimento pedagógico da "natureza da matéria" de bolsistas brasileiros participantes de uma programa de iniciação à docência [Pedagogical knowledge on "nature of matter" of brazilian scholars of a pre-service teacher program]. Educación Química, 25 (3), 363-379.

Scheibe, L. (2010). Valorização e formação dos professores para a educação básica: Questões desafiadoras para um novo plano nacional de educação [Basic education teachers' training and valuation: Challenging questions for the new national plan for education]. Educação \& Sociedade, 31 (112), 981-1000.

Shulman, L. S. (2004). Research on teaching: A historical and personal perspective. In: SHULMAN, L. S. The wisdom of practice: Essays on teaching learning, and learning to teach. San Francisco: Jossey-Bass, 364-381.

Silva, G. G. (2015). Significações do PIBID à formação para a docência na percepção de licenciandos em Ciências da Natureza/Química do IF-SC/SJ [Significations of the PIBID to the education for teaching in the perception of undergraduates in Sciences of the Nature/Chemistry of IF-SC/SJ]. (master's thesistação de mestrado, Federal University of Santa Catarina, Santa Catarina, Brazil). Retrieved from https://repositorio.ufsc.br/handle/123456789/134949

Sofianidis, A., \& Kallery, M. (2016). Assessing students' perceptions of their physics teachers' pedagogical content knowledge. In: Jari Lavonen; Kalle Juuti; Jarkko Lampiselkä; Anna Uitto; Kaisa Hahl (Org.). Science education research: Engaging learners for a sustainable future. 4 ed., Helsinki: E-Book Proceedings of the ESERA 2015 Conference, 2313-21319.

Streiner, D. L. (2003). Being inconsistent about consistency: When coefficient alpha does and doesn't matter. Journal of Personality Assessment, 80 (3), 217-222.

Tuan, H. L., Chang, H. P., Wang, K. H., \& Treagust D. F. (2000). The development of an instrument for assessing students' perceptions of teachers' knowledge. International Journal of Science Education, 22 (4), 385-398.

Van Driel, J. H., Verloop, N., \& De Vos, W. (1998). Developing science teachers' pedagogical content knowledge. Journal of Research in Science Teaching, 35 (6), 673-695.

Vianna, H. M. (1976). Testes em educação [Education tests]. 2. ed. São Paulo: Ibrasa.

Vieira, S. (2009). Como elaborar questionários [How to elaborate questionnaires]. 1.ed. São Paulo: Atlas.

\section{Appendix}

This instrument aims to recognize and record the perceptions of high school students about the PCK of PIBID pre-service teacher's. This instrument is an adaptation of the proposal of Jang, Guan and Hsieh (2009).

This set of statements aims to recognize and record the perceptions of high school students about the PCK of PIBID pre-service teacher's.

Analyze the statements that follow and use the scale below to express how are your views to it, considering the Pibid pre-service teacher's__ during the implementation of their classes this year. Be sure to give an scale for all statements. Mark the scale that corresponds to your perception.

\begin{tabular}{ll}
\hline 0 & I do not remember / I do not know \\
\hline 1 & Never occurred never in teaching practice \\
\hline 2 & Seldom occurred in teaching practice \\
\hline 3 & Sometimes occurred in teaching practice \\
\hline 4 & Often occurred in teaching practice \\
\hline 5 & Always occurred in the teaching practice \\
\hline
\end{tabular}


Keysy S. C. NOGUEIRA, Carmen FERNANDEZ. The reliability of an instrument to measure teacher knowledge from the perspective of learners in the context of PIBID

PROBLEMS

OF EDUCATION

IN THE $21^{\text {st }}$ CENTURY

Vol. 76, No. 1, 2018

Scale 85

\begin{tabular}{lllllll}
\cline { 3 - 5 } Category & Statements & 0 & 1 & 2 & 3 & 4
\end{tabular}

(SMK) 2. My teacher explains clearly the content of the subject.

3. My teacher knows how theories or principles of the subject have been developed.

4. My teacher selects the appropriate content for students.

5. My teacher knows the answers to questions that we ask about the subject.

6. My teacher explains the impact of subject matter on society.

7. My teacher knows the whole structure and direction of this SMK.

Instructional 1. My teacher uses appropriate examples to explain concepts

Representation \& related to subject matter.

Strategies (IRS) 2. My teacher uses familiar analogies to explain concepts of subject matter.

3. My teacher's teaching methods keep me interested in this subject.

4. My teacher provides opportunities for me to express my views

during class.

5. My teacher uses demonstrations to help explaining the main concept.

6. My teacher uses a variety of teaching approaches to transform subject matter into comprehensible knowledge.

7. My teacher uses multimedia or technology to express the concept of subject.

Instructional Ob- 1. My teacher makes me clearly understand objectives of this

jective \& Context course.

(IOC)

2. My teacher provides an appropriate interaction or good atmosphere.

3. My teacher pays attention to students' reaction during class and adjusts his/her teaching attitude.

4. My teacher creates a classroom circumstance to promote my interest for learning.

5. My teacher prepares some additional teaching materials.

6. My teacher copes with our classroom context appropriately.

7. My teacher's belief or value in teaching is active and aggressive

Knowledge of 1. My teacher realizes students' prior knowledge before class..

Students' Understanding (KSU)

2. My teacher knows students' learning difficulties of subject

before class.

3. My teacher's questions evaluate my understanding of a topic.

4. My teacher's assessment methods evaluate my understand-

ing of the subject.

5. My teacher uses different approaches (questions, discussion,

etc.) to find out whether I understand.

6. My teacher's assignments facilitate my understanding of the subject.

7. My teacher's tests help me realize the learning situation. 
Keysy S. C. NOGUEIRA, Carmen FERNANDEZ. The reliability of an instrument to measure teacher knowledge from the perspective of learners in the context of PIBID

OF EDUCATION

IN THE $21^{\text {st }}$ CENTURY

Vol. 76, No. 1, 2018

86

\section{Comments:}

During the pre-service teacher class: ___ (name of the pre-service teacher)

do you have any learning difficulty? If you want to comment on the student teacher, please use this space.

Received: January 17, 2018

Accepted: February 25, 2018

Keysy Solange Costa Nogueira
PhD Student at Interunities Graduate Program in Science Education, University of São Paulo, Rua do Matão, 1371 - 05508-090 Cidade Universitária, São Paulo, Brazil.

E-mail: keysynogueira@usp.br

Website: http://sites.usp.br/pequim

Carmen Fernandez
$\mathrm{PhD}$ in Chemistry, Associate Professor, Institute of Chemistry, University of São Paulo, Av. Prof. Lineu Prestes, 748 - Butantã - São Paulo - SP, 05508000, Brazil.

E-mail: carmen@iq.usp.br Website: http://sites.usp.br/pequim 